\title{
Link Between Language And Character Development: People's Perception
}

\author{
Deji-Afuye Oladunni 0. (Mrs) \\ Department of General Studies \\ College of Education, Ikere Ekiti. \\ Obadare Felicia Tomi (Mrs) \\ Department of General Studies, \\ College of Education, Ikere Ekiti.
}

\begin{abstract}
This study addressed the importance of language for character and personality development. This was done in the perception of the respondents to the study. Two hundred (200) participants from Ikere Local Government Area of Ekiti States, Nigeria were randomly selected as the sample for this study. A self-developed questionnaire with Yes and No options was validated and administered to the respondents. The data collected were analyzed using chi-square analysis. The findings of the study showed that the use the language will significantly enhance character education, hence character development; and that the kind of language an individual is exposed to shapes the kind of character that is developed in such an individual. It is therefore recommended that the society should be well informed about the role language plays in the lives of its citizens; all stakeholders should be involved in character education program for every citizen; and that, character values should be integrated into all subjects in our schools.
\end{abstract}

Keywords: Character development, language, character

\section{INTRODUCTION}

Language is a system of sounds or vocal symbols by which human beings communicate experience. Akindele and Adegbite (2005) assert that Language is God-given and it is a peculiarity of mankind. No other creature can use language to communicate his love, aspirations, goals, fears, like man. It even helps us to think, dream and verbalize our thoughts. With the use of language, our dreams are translated to tangible and handable things. Akindele and Adegbite (2005) also assert that man uses language to communicate his individual thoughts, inner feelings and personal psychological experience. Okanume and Odokara (2012) opine that language is a means of individual self expression.

Gorrell (1975) observes that 'A person's use of language as the basis for his representing and exploring the world around him channelizes his thinking processes.' In other words, it is language that decides the character of an individual. Language reveals inner or internal thoughts, opinions or feelings of an individual. When you read or hear statements made by people, you easily understand their thinking processes and hence, their personality and identity. This explains the fact that language is central to ones identity as an individual and as a marker to recognize each personality. It is also seen that language is used to express or evoke the attitudes of its users - both speakers and hearers. 
As a means of communication, language carries culture, and culture carries the entire body of values by which it users come to perceive themselves and their place in the world. Thus, it is not out of place to say that language has enormous significance to human existence. Expressing how fundamental language is to human experience, Boroditsky (2009: 2) says "But what would your life be if you had not learned a language? Could you still have friends, get an education, hold a job, start a family...it is hard to imagine life without it."

\section{Language and Character Education}

In an ideal society, according to Okpo (2015), the first step towards development is the overall development of the citizens. No society thrives or advances without intense desire for character development which can mainly be achieved through character education. It has been said that, "character education is as old as education itself". The effort to understand and develop character extends into prehistory and has been universally recognized. This effort include the teaching of individual persons in a manner that will help them develop variously as moral, civic, good mannered, well behaved, non-bulling, healthy, critical, successful, traditional, compliant, socially acceptable beings.

The link between language and education cannot be overemphasized. Education and language are closely interrelated because the content of education is imparted through the medium of language. Education, whether formal or informal can only be facilitated with the use of language (Olaoye, 2013). Dewey in Obadare and Fasuyi (2003) believed that education is a dynamic process which helps to mould the personality, the character, and behaviour of a person in a positive direction. According to Ottaway (1962:42), "Education is the process of preparing people to fit into this complex social structure and to play particular social roles as members of more than one institutional group." Ige (2000) has described language as a basis of any educational process because it enables an individual to develop mentally, psychologically, socially and emotionally from their mentors such as teachers, counselors, and with their peers. The kind of language one is exposed to can have a positive or negative effect on ones character building traits. In a society where it is uncommon on television, in movies, in songs through social media and even in homes not to use swear words, foul language, vulgar slangs, profanities and the like, the citizens tend to develop with the trend. Some people, especially, the youth even feel that vulgar slangs or profanities heard on television or social media are normal and acceptable aspect of everyday language and so, do not really see anything bad in using them.

Oyetunde (2013) identifies behaviours that are considered undesirable as corruption, bribery, fraud, murder, sexual assault or harassment, sexual promiscuity, sexual deviance, illiteracy, violence, aggression, drug and alcohol abuse, rape, lack of reading culture, intellectual laziness, passivity/lack of authority (as opposed to active learning), theft, robbery, arson, indecent dressing, examination malpractices and so on. On the other hand, Osalusi and Owoseni (2006) identify some values to be imbibed as patriotism, responsibility, self-discipline, self-respect, respect for elders, patience, perseverance, truthfulness, devotion and dedication to duty, sexual morality, brotherliness, tolerance, cooperation, integrity, modesty, good neighbourliness, forgiveness, social Justice, Faithfulness and contentment.

\section{Statement of the Problem}

That there is moral decadence in our society is purely stating the obvious. Moral decadence stares us in the face everywhere we go; home, church, mosques, markets, primary school, secondary, tertiary institution. The list is endless. Children are heady and rebellious while adult too fail to exhibit good conduct for the younger generation to emulate. According to Aja 
(2006), moral decadence in Nigeria is at its peak and this is evident in the numerous reports of activities of fraudsters, ritual killings, corruption in high places, murder, and suicide.

It is observed that we have many educated people who do not exhibit appropriate character. The use of hard drugs by primary school pupils is not shocking news anymore. All known social vices have come to take abode with us - cultism, robbery, thuggery, armed robbery, drug addiction, cyber crime, suicide, pornography, lawlessness, marital unfaithfulness, alcoholism, bribery, sexual promiscuity, examination malpractice, incest, indecent dressing, prostitution and lately kidnapping are all our neighbours. Osalusi and Owoseni (2006) assert that vices are evil and detrimental to national development of any country. In the traditional African society, these were unheard of. Hence, in the National Policy on Education, there are beautiful values to be inculcated but instead of getting it right, Nigeria is producing well educated and certificated people without good character. This paper is therefore premised on the need to examine whether language serve as a tool for positive character development in our society.

\section{Research Questions}

1. Will language use affect character development?

2. Will language serve as a tool for character development?

3. Will the kind of language an individual is exposed to shape the kind of character that is developed in such an individual?

\section{Research Hypotheses}

Ho1: There is no significant effect of language on character development.

Ho2: There is no significant relationship between language and character development.

Ho $_{3}$ : There is no significant relationship between linguistic exposure and character development.

\section{RESEARCH METHOD}

This study is a descriptive design of survey type.

\section{Population Sample}

The sample of this study consists of 200 respondents purposively selected from a population of Ikere Local Government Area of Ekiti State, Nigeria.

\section{Research Instrument}

Questionnaire was used as instrument for data collection which was validated by experts in the field of education and reliability test of 0.94 was observed through split-half method.

\section{Data Analysis}

The data obtained was subjected to statistical test through the use of Statistical Package for Social Science (SPSS). Descriptive and inferential statistics such as percentage \& mean and chisquare were used to provide answers to the research questions and hypotheses in the study.

\section{Data Presentation}

The results are presented in the table below 
Table 1: Language as a Tool for Character Development

\begin{tabular}{|l|l|c|c|c|c|}
\hline S/N & \multicolumn{1}{|c|}{ ITEMS } & YES (\%) & NO (\%) & MEAN & DECISION \\
\hline 1. & $\begin{array}{l}\text { It is possible to attain moral value through } \\
\text { language and character education. }\end{array}$ & $120(60 \%)$ & $80(40 \%)$ & 1.60 & Yes \\
\hline 2. & $\begin{array}{l}\text { The study of language enables individuals to } \\
\text { develop mentally, psychologically, socially and } \\
\text { emotionally. }\end{array}$ & $150(75 \%)$ & $50925 \%)$ & 1.75 & Yes \\
\hline 3. & $\begin{array}{l}\text { Language facilitates the teaching of basic } \\
\text { human values such as respect, honesty, } \\
\text { kindness, generosity, courage, freedom and } \\
\text { equality. }\end{array}$ & $148(74 \%)$ & $52(26 \%)$ & 1.74 & Yes \\
\hline 4. & $\begin{array}{l}\text { Language helps an individual to develop } \\
\text { acceptable behaviour. }\end{array}$ & $130(65 \%)$ & $70(35 \%)$ & 1.65 & Yes \\
\hline 5. & $\begin{array}{l}\text { Language facilitates/fosters ethical and } \\
\text { responsible attitudes. }\end{array}$ & $\begin{array}{l}145 \\
(72.5 \%)\end{array}$ & $55(27.5 \%)$ & 1.73 & Yes \\
\hline 6. & $\begin{array}{l}\text { Character can be developed through teaching } \\
\text { linguistic politeness. }\end{array}$ & $180(90 \%)$ & $20(10 \%)$ & 1.90 & Yes \\
\hline 7. & $\begin{array}{l}\text { Individuals are able to express themselves } \\
\text { acceptably by using appropriate linguistic } \\
\text { choices. }\end{array}$ & $120(60 \%)$ & $80(40 \%)$ & 1.60 & Yes \\
\hline 8. & $\begin{array}{l}\text { Individuals are able to develop good character } \\
\text { by using appropriate body language. }\end{array}$ & $170(85 \%)$ & $30(15 \%)$ & 1.85 & Yes \\
\hline 9. & $\begin{array}{l}\text { Appropriate behaviour can be developed } \\
\text { through the knowledge of the cultural } \\
\text { background of a language. }\end{array}$ & $156(78 \%)$ & $44(22 \%)$ & 1.78 & Yes \\
\hline 10. & $\begin{array}{l}\text { Language and cultural background determine } \\
\text { appropriate character development. }\end{array}$ & $120(60 \%)$ & $80(40 \%)$ & 1.85 & Yes \\
\hline
\end{tabular}

\section{$\bar{X} \geq 1.5$ indicate $^{\prime}$ Yes' $^{\prime}$ otherwise $^{\prime} \mathrm{No}^{\prime}$}

The result of analysis presented in Table 1 revealed that majority (60\%) of the respondents indicated that it is possible to attain moral value through language and character education, $75 \%$ agreed that the study of language enables individuals to develop mentally, psychologically, socially and emotionally, $72 \%$ agreed that language facilitates the teaching of basic human values such as respect, honesty, kindness, generosity, courage, freedom and equality, 65\% indicated that language helps an individual to develop acceptable behavior, $72.5 \%$ indicated that language facilitates or fosters ethical and responsible attitudes, $90 \%$ agreed that character can be developed through teaching linguistic politeness, $60 \%$ indicated that individuals are able to express themselves acceptably by using appropriate linguistic choices, $85 \%$ indicated that individuals are able to develop good character by using appropriate body language, 78\% agreed that appropriate behaviour can be developed through the knowledge of the cultural background of a language and $60 \%$ indicated that language and cultural background determine appropriate character development. The mean values in the table are greater than 1.50 which implies that majority of the respondents agreed with the statement that language serves as a tool for character development. 


\section{Test of Hypotheses}

Hypothesis 1: There is no significant effect of language on character development.

Table 2:

Chi-square of effect of language on character development

\begin{tabular}{|l|c|c|c|c|}
\hline & Calculated Value & Df & Asymp. Sig. (2-sided) & \multirow{2}{*}{ Table value } \\
\hline Pearson Chi-Square & $240.50^{\mathrm{a}}$ & 9 & 0.00 & \multirow{2}{*}{16.92} \\
\cline { 1 - 4 } Likelihood Ratio & 243.73 & 9 & 0.00 & \\
\cline { 1 - 2 } Linear-by-linear Association & 108.32 & 1 & 0.01 & \\
\hline N of Valid Cases & 200 & & & \\
\hline
\end{tabular}

$\mathrm{P}<0.05$

Table 2 reveals that $\mathrm{X}^{2}$ cal. $=240.50, \mathrm{df}=9$, and $\mathrm{X}^{2}$ value $=16.92$ at 0.05 level of significances The result shows that $X^{2}$-cal. (240.50) is greater than $X^{2}$ value (16.92) at 0.05 level of significance. The null hypothesis is rejected. This implies that there is significant effect of language on character development.

\section{Hypothesis 2: There is no significant relationship between language and character development.}

Table 3: Chi-square of relationship between language and character development

\begin{tabular}{|l|c|c|c|c|}
\hline & Calculated Value & Df & Asymp. Sig. (2-sided) & Table value \\
\hline Pearson Chi-Square & $284.77 a$ & 9 & 0.00 & \multirow{2}{*}{16.92} \\
\cline { 1 - 4 } Likelihood Ratio & 309.02 & 9 & 0.00 & \\
\hline Linear-by-linear Association & 173.23 & 1 & 0.00 & \\
\hline N of Valid Cases & 200 & & & \\
\hline
\end{tabular}

$\mathrm{P}<0.05$

Table 3 reveals that $\mathrm{X}^{2}$ cal. $=284.77, \mathrm{df}=18$, and $\mathrm{X}^{2}$ value $=16.92$ at 0.05 level of significances. The result shows that $X^{2}$ cal. (284.77) is greater than $X^{2}$ value (16.92) at 0.05 level of significance. The null hypothesis is rejected. This implies that there is significant relationship between language and character development.

\section{Hypothesis 3: There is no significant relationship between linguistic exposure and character development.}

Table 4: Chi-square of relationship between linguistic exposure and character development.

\begin{tabular}{|l|c|c|c|c|}
\hline & Calculated Value & df & Asymp. Sig. (2-sided) & Table value \\
\hline Pearson Chi-Square & $151.95^{\mathrm{a}}$ & 9 & 0.00 & \multirow{2}{*}{16.92} \\
\cline { 1 - 4 } Likelihood Ratio & 168.56 & 9 & 0.00 & \\
\hline Linear-by-linear Association & 11.10 & 1 & 0.01 & \\
\hline N of Valid Cases & 200 & & & \\
\hline
\end{tabular}

$\mathrm{P}<0.05$

Data presented in Table 4 reveals that $\mathrm{X}^{2}$ cal. $=151.95, \mathrm{df}=9$, and $\mathrm{X}^{2}$ value $=16.92$ at 0.05 level of significances. The result shows that $\mathrm{X}^{2}$ cal. (151.95) is greater than $\mathrm{X}^{2}$ value (16.92) at 0.05 level of significance. The hypothesis is rejected. This implies that there is significant relationship between linguistic exposure and character development.

\section{DISCUSSION OF FINDINGS}

The findings of this study revealed that language serves as a tool for character development. The study described language as possible way of attaining moral value. This corroborates the assertion made by Obura (2013) that language enables individuals to develop mentally, 
psychologically, socially and emotionally. Hence, language facilitates the teaching of basic human values such as respect, honesty, kindness, generosity, courage, freedom and equality. It helps an individual to develop acceptable behaviour in the society. Language fosters ethical and responsible attitudes. Leech (1983) and Mariani (2016) explain that in the effort to develop better character in citizens, there is the need to implement politeness principles. Politeness is mostly expressed in the language used. Language learning and usage processes containing politeness values in the society are inseparable from the development of individual character.

This study also revealed that appropriate behaviour can be developed through the knowledge of the cultural background of the language an individual is exposed to. This findings is in agreement with Aubrey (2008) who posits that the knowledge of the cultural background of a language is very essential if character will be developed. Language is so entwined with culture and the knowledge of this give room for the learners and users to be able to attach correct meanings to various linguistic items and also use them appropriately.

\section{CONCLUSION}

Based on the findings of the study, it was concluded that language and linguistics exposure are essential tools for character development both mentally, psychologically, socially and emotionally. It enhances and facilitates the teaching of basic human values such as respect, honesty, kindness, generosity, courage, freedom and equality in the society.

Character education in today's world is essential because many have been exposed to consumption of inappropriate, devastating and uncontrolled internet products which have some information that have corrupted their character. There have been many negative influences through the media, and other external forces that find their way into people's lives in today's culture.

The following recommendations are made:

\section{RECOMMENDATIONS}

- The society should be well informed about the role language plays in the lives of its citizens.

- All stakeholders should be involved in character education program for every citizen.

- Character values should be integrated into all subjects, particularly the English learning in our schools. This will enable the students to communicate effectively and efficiently in writing and speaking. It will as well improve their intellectual, emotional and social abilities.

- Moral instruction must be emphasized and taught in the language of the environment.

- Mothers must be alive to their duties and teach their children in plain language, the values we hold in high esteem and the vices that we detest.

- Mass media must be used vigorously in different Nigerian languages to enlighten the people - our values and vices

- The curriculum of Traditional education should be emphasized in the different languages. Many of the present generation do not know it.

- Government should be vigorously involved in the music that our musicians produced. The musicians must be made to produce music that is reformatory and not plunging our youths further into vices. 


\section{References}

Aja, J.O. (2006). Enhancing Behaviors among the Nigerian Youths: The Role of Women in JOWICE Journal of Women in Colleges of Education. (10) 8; 87 - 90.

Akindele, F. \& Adegbite, W. (2005). The Sociology and Politics of English in Nigeria. OAU Press, Ile Ife.

Aubrey, N. L. (2008). "The Relationship between Language and Culture and the Implications for Language Teaching." Article for TEFL.net.

Boroditsky, L. (2009) How does our language shape the way we think? https//www.edge.org/conversation/lera_borditsky

Gorrell, J.J. (1975) Language and self: A dissertation. http//www.thesaarc.com

Ige, S.B. (2000) Language as a tool for moving education forward in the year 2000 and beyond. Literature and linguistics in the $21^{\text {st }}$ century. Kaduna; NCCE Publication.

Leech, N. G. (1983) Principles of Pragmatics London and New York: Longman Group Ltd.

Mariani, N. (2016) “Developing Students' Intelligent Character through Linguistic Politeness: The case of English as a Foreign Language Indonesia Students” English Language Teaching. (9) 1; 101-106.

Obadare, F.T \& Fasuyi, A.O. (2003). The Philosophy of Pre-Primary and Primary Education, Ikere Ekiti, Oguntoyinbo Publishers.

Obura, D. (2013) The Contribution of Language to Character Education. International Conference to Commemorate the $45^{\text {th }}$ Anniversary of Veteran Bagun Nusantara University, Sukoharjo, Indonesia.

Okanume, A.C \& Odokara, B.C. (2012). Language Education: the tool for Women enlightenment for national Peace and Security. Being a paper presented at the $17^{\text {th }}$ Annual National Conference of Association of Women in Colleges of Education Between 9th - 12th October, 2012 at Federal College of Education (Technical), Umunze.

Okpo, O. (2015) Moral Education and Nigeria's Development. Sophia: An African Journal of Philosophy. 15(20) 1-6.

Olaoye, A.A. (2013) Towards vision 20-2020: The role of language and literature in National Development Theory and Practice in Language Studies, 3(5) 748-753

Osalusi, F.M \& Owoseni, A.A. (2006). An Introduction to Religions and Moral Education, Ado Ekiti, Frank Ayo Press Ottaway, A.K.C. (1962) Education and society: an Introduction to the Sociology of Education, London, Routledge and Kegan Paul.

Oyetunde, T.O. (2013). Curbing Social Ills: The Role of the Academia. A Key-Note Address Presented at the $18^{\text {th }}$ National Conference of the National Association of Women in Colleges of Education (WICE) held between 7 th 11th October, 2013 at the Federal College of Education, Kontagora, Niger State. 